\title{
"But what a place / to put a piano": Nostalgic Objects in Robert Minhinnick's Diary of the Last Man
}

\section{ABSTRACT}

In 2003, Martin Rees referred to the present as "mankind's final century." A few years later, Slavoj Žižek wrote that humankind is heading towards "apocalyptic zero-point," when the ecological crisis will most probably lead to our complete destruction. In his 2017 collection, Diary of the Last Man, Welsh poet Robert Minhinnick offers readers a meditation upon Earth at a liminal moment-on the brink of becoming completely unpopulated.

Imagining a solitary human being, living in the midst of environmental collapse, Minhinnick yet entwines different voices-human and nonhuman-operating across vast spans of time. The speaker of the poems moves freely through different geographies and cultural contexts, but the voice that starts and ends the journey, seems to be the voice of the poet himself: he is the last man on earth, a survivor of ecological disaster.

The paper discusses Minhinnick's collection as a projection of the world we now inhabit into a future where it will exist only in the form of nostalgic memories. The analysis focuses on the role of objects in the construction of the world-within-the poem, where the fragments of human civilization are being claimed by forces of the environmentengulfing sand, progressive erosion-forming a retrospective vision of our "now" which will inevitably become our "past."

Keywords: Robert Minhinnick, Welsh poetry, memory studies, ecology. 
Robert Minhinnick's collection of poems, Diary of the Last Man ${ }^{1}$ (2017), offers a vision of a post-apocalyptic world, in which a lonely wanderer, perhaps the last representative of the human race, passes his nights experiencing nightmares and his days eating scurvygrass, burying his excrement, living a "castaway life" which he despises.

The world we encounter in the poems exhibits features of a dystopia which, as Gregory Claeys states, not only describes "negative pasts and places we reject as deeply inhuman and oppressive," but also "projects negative futures we do not want but may get anyway" (498); and so it "increasingly defines the spirit of our times" permeated by "long-term anxieties" (498) about climate change and the destruction of the natural environment. By imagining the plight of a solitary individual who survives an environmental collapse, Minhinnick offers such a dystopian projection. He takes us into a time when the world we now inhabit will exist only in the form of nostalgic memories; a time that could be described, in the words of Martin Rees, as mankind's "final hour," or in the words of Slavoj Žižek, as the "apocalyptic zero-point" when the ecological crisis leads to our complete destruction (x); the time when "apparently omnipotent humanity" ends its course (Claeys 498) ${ }^{2}$.

In these conditions, all possible cultural points of reference slowly lose their integrity, becoming precarious and ephemeral, and offering no guidance. On his journey through a post-apocalyptic world, the speaker of Minhinnick's poems-the "Last Man"-encounters multiple objects which constitute the detritus of the human world, and which evoke memories. The aim of this article is to analyze the role of such objects in Minhinnick's poems, using selected examples; and to examine, in particular, how they are used to construct a vision of a world deprived of human existence, and so of human meaning. Objects function in the poems as "touchstones" for the speaker, who has to find his place in a landscape which is becoming more and more "Other," removed from human values and hierarchies.

In "Nostalgia," the speaker finds a computer that once belonged to the Prime Minister, now abandoned in the empty quarters of Number 10, Downing Street. It brings back "all the meaningless secrets," "cover-ups" and "scandals" (6), the less-than-admirable legacy of the human era; and it reduces the lonely traveller to tears as he breaks the password, and goes through the files: "Those were the days" he cries, "great days," "the last

1 Subsequently referred to as Diary.

2 The phrase "final hour" is taken from the title of the book by Martin Rees published in 2003. The full title of the book is Our Final Hour: A Scientist's Warning: How Terror, Error, and Environmental Disaster Threaten Humankind's Future In This Century-On Earth and Beyond. 
of our lives" ("Nostalgia" 11). The speaker of the poems (the chroniclerwanderer) does not collect objects, but merely encounters them on his way; nevertheless, they function as "linking phenomena" (or "linking objects”), to use Vamik D. Volkan's term: they represent a lost thing for someone in mourning (49). In one poem, for example, an abandoned piano offers a "a symbolic bridge ... to the representation of that which is lost" (Volkan 49) -in this case, human music. Such objects may be termed "nostalgic" in the sense defined by Laura Impert and Margaret Rubin, who analyze what they call an "embodied nostalgia, a sensory and somatosensory experience of the past in the present that evokes cherished and/or painful memories" (692). Drawing on Marcel Proust's treatment of involuntary memory in $\grave{A}$ la recherche $d u$ temps perdu, and their own experience as psychoanalysts, the authors confirm that nostalgia

is often linked to the various objects we keep as time passes. Evocative objects and memorials weave ... [human] affects around loss and mourning on a sensory, physical level, functioning as touchstones that hold life's painful losses. Just like any given memory tells a story, so do the objects we choose to keep. ... [They] summon the time that had vanished.... Evocative objects are ... registered in our bodies as we touch them, or pick them up and look at them or smell them once again. (700)

Such objects provide a locus for externalized contact between aspects of the representation of that which has been lost. The one who mourns sees them as containing elements of himself/herself and of the lost object which, in the case of the speaker in Minhinnick's poems is, in a sense, the whole human civilization. The objects encountered anchor the speaker in the realm of the human, connecting him to the past as a source of his identity, while, all around him, traces of human civilization undergo progressive erosion.

Together, the objects in the poems may be said to trigger a nostalgic response, in the traditional sense of an unappeased yearning to return. As Barbara Cassin explains, the word is "made up of nostos, 'return,' and algos, 'pain,' 'suffering'"; and it refers to both "the suffering that has a hold on you when you are far away and the pains you must endure in order to return" (5). In the seventeenth century, when nostalgia was first classified as an illness (Cassin 5), this "return" was understood as a return home, to the place of origin, or simply the place one identifies with, which is associated with safety, with all that is local, comprehensible, and recognizable. In Minhinnick's collection, "home" has to be understood not as a geographical location, but rather a particular moment, the anthropocentric era in the history of the world, developed around human needs and desires; a period which, long as it might have been, is now (apparently) coming to an end. 
Throughout the collection, Minhinnick entwines different voiceshuman and non-human-operating across vast spans of time. The speaker of the poems moves freely through different geographies and cultural contexts, but the voice that concludes the journey, like the voice that initiates it, seems to be the voice of the poet himself: be is the last man on earth, the last survivor of the species on the brink of extinction, who finds himself in a liminal space, between the end of the old era and the beginning of the new-the threshold between the populated and unpopulated world. As Barbara Cassin suggests, "not yet" (15) is what nostalgia is most interested in: the liminal space between pleasure and pain, here and there, past and present. The speaker in Diary is himself, in a sense, the "threshold," the last man standing; the objects he encounters are similarly "liminal" as they are inscribed with the old stories, recognizable only by him, the last traveller and the last chronicler, who asks, it seems rhetorically, "who is left to read what I must write?" ("The London Eye" 19).

The objects open up the past, and bring it back in the form of filmlike images. In the poem "The London Eye," the speaker enters an abandoned "Traveller's Club" and notes objects such as old maps and diaries. Although the address is not mentioned we may assume that he is in the famous Traveller's Club situated at 106 Pall Mall Street, established in 1819, which originally excluded from membership anyone "who has not travelled out of the British islands to a distance of at least five hundred miles from London in a direct line" (Cunningham). This is an institution, then, which epitomizes an era of great explorations and imperial ambitions, and is above all "unmistakably English" (Wilson), saturated with British history and tradition. The speaker inscribes himself into the line of explorers who came before him: "I sit in the travellers' armchair / and I sip the travellers' gin" ("The London Eye" 20-21). The objects he touches, admires and tastes, summon stories of great deserts, "Saharan, Sonoran and thirsty Thar" ("The London Eye" 13), and isolated vignettes from the past, such as one of "caribou-skinned aristocrats / knocking there pipes out on Greenland's lava" ("The London Eye" 14-15). In the present context, however, the club's lavish interiors seem absurd, and its exclusive character meaningless. The speaker is also an explorer, yet his account of his journey through the wasteland of civilization may be written in vain, as no readers await it. The poem, like others in the collection, depicts a future of recognizable landmarks which have their place in a complicated net of cultural associations. Depopulated and deprived of their practical and representative functions, they now seem to question the values that prompted their existence and ensured their status. Although they have not yet fallen into decay, they occupy a liminal position, as they are on the verge of turning into ruin, a condition which 
has been defined by Brian Dillon as "essentially an accommodation between nature and culture, the artificial object sliding imperceptibly towards an organic state, until in the end nature has its way and we can no longer legitimately speak of a 'ruin' at all" (13). The implied future (i.e. slow ruination) of the Traveller's Club, an abandoned architectural masterpiece, evokes a sense of nostalgia and endows the objects found in the club with additional meaning. To use Georg Simmel's words: as "countless things, once immersed in life" and now "cast on its bank," they embody "the present form of the past life" (23). As the speaker comes into contact with the objects-books, maps, grains of sand from Sahara, a pipe, a bottle of gin-they "command in spirit the entire span of time ... the past with its destinies and transformations ... gathered into this instant of an aesthetically perceptible present" (23). However, the speaker is the only "traveller" left to perceive it. He confirms his solitude:

No,

no-one here.

Nobody.

The only soul my own. ("The London Eye" 2-5)

The very title of the poem (“The London Eye”) evokes several meanings. Firstly, of course, it is a familiar city landmark, and a point of reference on the landscape which the collection is mapping; but it also connects the "future" time of the action, with the past (i.e. our own "present" time as readers). It is an object which both the reader and the speaker of the poem recognize in the worlds they inhabit. Additionally, its name refers to the act of looking: the phrase "London Eye" can be understood as an "eye" cast over the city. There is, indeed, only one pair of human eyes left in this future-world; and there is a suggestion, perhaps, that in time, only the artificial, non-human "eye" will remain, still "gazing." Given the homophonous character of the words "eye" and "I," the "London Eye" may also denote the speaker as the London "I": a lonely presence in the city, the last storyteller, who gazes and reports on his journey, with no hope of any future audience.

$*$

Diary begins with an extended subsection, composed of twenty-three poems, which gives the collection its name. At the start of the first poem, "Prophecy," the speaker is in a church made of driftwood: 
Perhaps

I am the last man.

Perhaps I deserve to be.

So in this driftwood church

I hum my hymn of sand. (1-5)

The "hymn of sand" is an evident attempt at prayer. As Suzannah V. Evans points out, the poem is "a good example of Minhinnick's gift with sound: 'hum' and 'hymn' reverberate across each other, the combined sounds extending to suggest the gulf of empty time that the speaker suddenly finds himself in" (Evans). Despite the fact that he is in a structure associated with human spiritual endeavour, the speaker is adrift, and the church itself is merely an empty shell, a remnant of human culture, with no power to transcend or to console; where, as we learn, "any god / would be welcome here. /Any god at all" ("Prophecy" 6-8). In this poem, characterized by brevity and formal austerity, there are no references to particular objects which could characterize the world inhabited by the speaker (as occurs in "The London Eye"); nevertheless, it may itself be said to bear resemblance to a "found object." As Evans suggests, "like other fragments in Diary of the Last Man, the piece is perfectly formed, its shape suggestive of a medallion, washed up on the shore, something that could be picked up and held in the hand" (Evans). At the same time, the poem's terse and short lines suggest a state of suspension and waitingthe loneliness of this solitary "worshipper" who, like Beckett's Vladimir and Estragon, is waiting endlessly for God(ot) to arrive. The terseness also suggests, perhaps, the hollow sound of the speaker's words, as they reverberate in the surrounding silence. The speaker's solitude is further confirmed by the images of objects which start to appear in subsequent poems of the subsection: some are man-made, such as razor-wire or a child's shoe, scattered randomly across the post-apocalyptic landscape, and contributing to the general feeling of desolation. Some belong to the world of nature, like the "gold leaf" of a dispersing cloud ("Nocturne" 1), suggesting the beauty of a natural environment which can also, however, be a source of dread. The horror of human extinction is often communicated through the objects which appear in the "frame" of the traveller's gaze, such as the oyster shells, which in his mind turn into the countenances of old men eating their gruel. The image is disturbing, violent even, as we learn that the traveller treads on their faces with his boots, revealing their "blue craniums" "Oyster Shells" 5). The opening poem of the series (i.e. "Prophecy") introduces two elements which recur in many poems of the collection: sand (which is mentioned by the speaker) and water (suggested indirectly through the reference to the "driftwood" from which 
the church is made). These elements powerfully assert their presence, in particular, in the final poem, "The Sand Orchestra," in which the speaker comes to a dry plateau, and encounters a grand piano; and not an ordinary one, but a Bechstein, the most exquisite specimen of its kind, evidence of an advanced level of human craft. In this way, the abandoned instrument represents human culture, which is now irreversibly lost. In the context of a sand-covered landscape, with no sign of human presence, it can be seen as a synecdoche of human civilization; magnificent and absurd, deserted now, and at the mercy of the elements.

The speaker remembers his youth, the times when he thought, as an activist in the peace movement, that the end of the world would come with a blast of nuclear weapons, as a horrific but spectacular event, a powerful explosion. Now he knows that extinction in fact came quietly and slowly, with the continuous destruction of the natural environment. The main tool of the destruction, its final phase, was not fire, burning like the "hair of Blake's Christ" ("The Sand Orchestra" 20), as the activists had believed, but rather sand, which invades all interiors, amalgamates all shapes, smooths all edges, disfigures the landscape, erases the horizon, and makes all the elements of the world indistinguishable. The piano can be seen as an evocative object, as defined by Impert and Rubin, which carries in itself a reminder of loss, and "summons the time that had vanished" (700). In this case, the piano refers back to the world of human music, even though it can no longer fulfil its original function; it is only "played" now by the wind and the sand. The Bechstein piano is not only a synecdoche of lost civilization; in the poem, it also bears the "shadow" of a different object entirely. To the speaker, the piano lid suggests the sail of a ship on the horizon - an object which the traveller has no chance to see in a landscape which is covered in sand. The image of the ship underpins the image of the piano, and constitutes its spectral double.

Ian Gregson notes that there is, in Minhinnick's poetics, an "increasing tendency for places to overlap" (49). This is often achieved through the introduction of images of animate or inanimate objects which then undergo transformation. In his 2002 poem “The Cormorant," for example, a seabird figuratively becomes a piece of war machinery, a "stealth-bomber out of the empty / quarter, trailing ... death / across the sky" (45-47). As Neil Alexander observes, the introduction of the image serves to "conflate the Porthcawl shoreline with the bomb-damaged cityscape of contemporary Baghdad. Such usage of juxtaposition and double focus in Minhinnicks's texts imply that the meanings of any given place are often dependent upon the relation it has with other places" (80). The piano/ship doubling conflates different time planes, rather than geographical locations: the anthropocentric past and the depopulated future. If we take into account 
the reference to Ulysses, however, the poem also brings into play a sense of "mythic time," which stands outside linear time-sequence-the idea of a clear and chronological beginning, middle and end-and is concerned rather with cyclicality. By inscribing the story of the lonely wanderer and the abandoned piano into a larger context of canonical literature (Homer and Greek Mythology on one hand; James Joyce's Ulysses on the other), the poet not only "conjoins the local and the global" (Alexander 81), individual and communal; but also envisages literature as a site of exchange, and positions his own voice in the long history of voices; and his own "diary" in the long procession of stories which have been told by those who read the landscapes they inhabit as "neither integral nor native" to them (Minhinnick, "Mouth to Mouth" 34).

The speaker in "The Sand Orchestra" links piano and ship through the power of association, knowing, of course, that the landscape is deprived of water. We may assume it has disappeared as the result of human action and ecological disaster. Surrounded by a desert, the speaker imagines a sea-shore; the piano, resembling a ship, evokes nostalgia for the sea, for water which could offer "a greener arena" ("The Sand Orchestra" 55) but which is nowhere to be seen, although the constant movement of sand in the poem itself resembles the movement of the ocean. It is a "sea" of sand, which engulfs everything. In this way, we may say that the image of the piano is a focal point of nostalgia for the lost human civilization, but also for the natural world destroyed by that civilization. Perhaps the poet is pointing to the fact that the former cannot survive without the latter; human music cannot survive in a world where the ocean has become a mere memory.

The object as "ship" suggests yet another context. The poem actually begins with the announcement that "Ulysses has not returned" ("The Sand Orchestra" 2). Ulysses, a Latinized version of the name of Odysseus, refers the reader to Joyce's famous novel, and indirectly to Homer's narrative poem, a canonical text in Western culture, whose main character is the epitome of the "traveller"-a nostalgic traveller, perhaps, as Barbara Cassin has suggested, calling The Odyssey the very "poem of Nostalgia" (5). Neil Alexander has analyzed the importance of the "beach" as an image in Joyce's Ulysses. In Chapter 3, Stephen Dedalus is walking alone on Sandymount Strand. He responds to or "reads the littoral landscape ... as a text composed of shifting and unstable layers. . . The shoreline is, for Stephen, a place of "ineluctable modality' (Joyce 31) . . . a protean landscape" (73). In the course of the chapter, Stephen remembers the past, his dead mother, and different moments in the history of Ireland. In all cases, his "location on the beach is symbolically crucial, for in this liminal zone, land and sea meet in an 
ongoing process of accumulation and erosion" (Alexander 74). It is "a landscape of continual change [representing] a condition of flux that Stephen discovers at the heart of the apparently solid material world" (Alexander 74). Similarly, the speaker of Minhinnick's poem is depicted in the midst of an environment whose main feature is its instability. In this case, the main destabilizing elements are sand, which claims the entire surroundings which moves in tides ("The Sand Orchestra" 39); and the wind, which as we learn, "dines on dunes" ("The Sand Orchestra" 29).

As Alexander notes, the "littoral landscape" constitutes a pivotal space in Minhinnick's oeuvre. His "expansive ... narratives often explore the seacoast and beaches of South Wales and around Porthcawl," articulating the "relationship between place and identity" (Alexander 75). The beach is present in many of his poems as an "eventful place of flux," "a shifting ground upon which" the poet explores his "ideas of home” (Alexander 74), the relationship between self and place, the human and non-human, people and nature, and the unavoidable conditions of "environmental entanglement" (Alexander 75). Minhinnick's ecological concerns, which he so often raises in the context of the "littoral zone" (Alexander 74) and its decline, are closely related in his texts to issues of attachment and alienation, rootedness and uprootedness, permanence and transience. This should not be surprising, perhaps, if we consider that "the prefix eco- is derived from Greek oikos 'the home or a place of dwelling"' (Bate 75; emphasis in original). The beach in Minhinnick's poetry is the "place of dwelling" abused by its inhabitants, "a landscape of exhaustion" ("Salvage" 19), a "coast poisoned / By people, crossboned with shipwreck" ("Salvage" 2324). The setting of "The Sand Orchestra" is not the sea-shore, but the idea of the sea underpins the tissue of the poem: the desert has a "littoral landscape" as its silent counterpart or spectral double. In other words, it is the absence of the sea which is being represented in the text. The poem refers to sand (the word is used 11 times in the poem), but it is, in a way, a poem about the sea which is no more. The sea is not referred to directly, but suggested by the piano/ship and its "sail" ("The Sand Orchestra" 57), by the movement of the sand, the line of the horizon; and perhaps most powerfully, by the character of Ulysses.

From the beginning, we learn that the speaker has been looking for Ulysses, who is nowhere to be found. In Homer's version of the story, of course, Odysseus finally returns to Ithaca (even if only for one night). The line, "Ulysses has not returned" ("The Sand Orchestra" 57) may suggest an alternative ending to the hero's mythical journey; or it may simply refer to an earlier point in the narrative, when the hero has yet to return, unlike the other Greek Warriors who made their way home after bringing Troy to its knees. 
The ship we subsequently encounter and recognize in the piano, might be interpreted as Odysseus's. Minhinnick describes the sound the sand makes on the piano as a "hissing" aria, and compares it to the song of a mermaid. This ragged music of extinction may evoke associations with the Sirens of The Odyssey. The Sirens try to lure the hero into the abyss, but fail, as he asks to be tied to the mast while he sails past their island, so as not to give in to their calamitous song and, as Cassin writes, so "lose his homecoming" (15). The object's double status as a piano/ ship seems to resonate in the context of another scene in The Odyssey, which also revolves around the idea of doubling. After his return to Ithaca, Odysseus has to set off again, this time inland; and (like the speaker of Minhinnick's poem) he reaches a land without a sea. His oar (which he carries in his arms) is mistaken by a passer-by for a winnowing fan. The passer-by is "assimilating" what he "does not know to and through [his] culture" (Cassin 22). Cassin suggests that he is “'integrating,' we might say today, foreignness and alterity" (Cassin 22). As the passer-by does not know the sea, he does not recognize the oar for what it is. The text offers two perspectives, that of the reader (and Odysseus) who knows what the object is; and that of the wayfarer, who does not know.

The misunderstanding and misrecognition produce the double image of the "oar/winnowing fan," as "the mark, the sure sign of the elsewhere" (Cassin 22) of a land far away from the Mediterranean (and so the sea). In Minhinnick's poem, the situation is different: the doubling is produced as a result of the fact that the speaker remembers the sea, and knows the difference between sea and sand, the "greener arena" "The Sand Orchestra" 55) and the "gold" plateau ("The Sand Orchestra" 53). His recognition of the resemblance between the piano lid and the sail does not imply an assimilation but, rather, the cultivation of strangeness. The gap between the two objects is even accentuated by the comparison-in the similarity found between dissimilar things. At the same time, the comparison plays on the shifting meaning of the object, in the absence of a human context to endow meaning. Cultural points of reference only exist in the speaker's mind; and the object obtains its double status through the power of memory. The speaker sees a sail in the piano lid, because he remembers the sea. Memory is the driving force that produces this image, and we share the speaker's gaze: we see the piano-as-ship through his eyes. In this way, Minhinnick invites us as readers, to consider a time and circumstance, in which the last man on earth might recall the last memory of the sea. In order to see a resemblance between piano lid and sail, one must know the sea; if we destroy the sea (the poem implies), this recognition will, finally, be impossible. We will all be like the wayfarer in The Odyssey; or we will not even be there, to "misunderstand" it at all. 
$*$

Minhinnick argues that "writers are witnesses ... it's the searching that counts ... writing is part of that search. It's one of the things that make us human" (Minhinnick, "Interview"). Through the persona of the speaker of the Diary, the "Last Man" who writes his lines in the face of the extinction of his own species, Minhinnick directs the reader's attention to the act of "witnessing" and "searching"-but also to language as an imperfect tool of expression and communication. For Stephen Dedalus in Joyce's Ulysses, the shoreline is a "space of multiple, overlapping inscription" (Alexander 72) which he can decipher by naming the objects and phenomena he encounters, exploring the mosaic of fragments: "signatures of all things I am here to read, seaspawn and seawreck, the nearing tide, the rusty boot. Shotgreen, bluesilver, rust, coloured signs" (Joyce 31). Discussing Minhinnick's work, Alexander has argued that, at times, the poet seems to follow "the lead of Joyce's Stephen Dedalus by reading the ... landscape as if it were a text" (81). This textualization of the environment, however, implies that the landscape is a "home," the place of our dwelling, which we can relate to and where we can find meaning. As Minhinnick observes, the problem is that, even as we live in the landscape, we also "live in language" ("Questions of the Woman who Fell" 63) and so our relation to the environment is always "culturally mediated" (Alexander 81). In his concern with ecological issues, the poet himself, as much as the poetic persona of the Diary, occupies a liminal position, as the very medium of expression estranges him from what he is trying to witness and explore. In "The Sand Orchestra," the speaker attempts to communicate with nature, but this only confirms his alienation:

Attention sand! I say

But after all these years the

sand ignores the sandman.

This is urgent I cry.

But may as well be talking to myself. (31-35)

We learn that "sand ... eats words / just as the wind / dines on dunes" ("The Sand Orchestra" 27-29). The implication is that human language may be coming to an end, together with all the sounds and forms it once produced.

In "The London Eye," the speaker states that "today might be the day / when all the great astonishments must cease" (22-23). Nevertheless, the collection ends with a moment of great astonishment. The final image - the last leaf of the "diary," one might say—is a single cinematic 
"frame," occupied by an object, the grand piano, as it again catches the speaker's attention:

Okay, after exhaustion sand summons extinction.

But what a place

to put a piano. ("The Sand Orchestra" 65-67)

The words foreground the aesthetic value of the image, its sublime beauty, which evokes a sense of awe and dread. The shadow of "extinction" ("The Sand Orchestra" 65) is almost literally cast over the last two lines, through the graphic layout of the text. The speaker's outburst is prompted by the clash between culture and nature, the wild landscape of the dunes and the man-made object. As Alexander observes, the contemporary ecological poet "occupies an interstitial space in which the tension between a desire to engage with nature directly and an abiding commitment to the artifice of language and poetic form has always to be negotiated" (81). Minhinnick's poetry is created out of this liminal space, which proves to be an "eventful place of flux" (Alexander 72), productive and continually challenging, where the poet seeks to bear "witness," to name the objects he encounters, even as meaning itself proves to be unstable under the fleeting human "gaze."

\section{Works Cited}

Alexander, Neil. "Shorelines: Littoral Landscapes in the Poetry of Michael Longley and Robert Minhinnick." The Beach in Anglophone Literatures and Cultures. Ed. Ursula Kluwick and Virginia Richter. London: Routledge, 2015. 71-86. Print.

Bate, Jonathan. The Song of the Earth. London: Picador, 2000. Print.

Cassin, Barbara. Nostalgia: When Are We Ever at Home? Trans. PascaleAnne Brault. New York: Fordham UP, 2016. Print.

Claeys, Gregory. Dystopia: A Natural History. Oxford: Oxford UP, 2018. Print.

Cunningham, Peter. "Victorian London Entertainment and Recreation Clubs-Travellers Club Handbook of London, 1850.” Victorianlondon. org. The Victorian Dictionary. Web. 25 May 2018.

Dillon, Brian. "A Short History of Decay." Ruins. Ed. Brian Dillon. London: Whitechapel Gallery, 2011. 10-19. Print.

Evans, Suzannah V. Rev. of Diary of the Last Man, by Robert Minhinnick. Nerwrelshreviere.com. New Welsh Review Jul. 2017. Web. 20 Apr. 2019. Gregson, Ian. The New Poetry in Wales. Cardiff: U of Wales P, 2007. Print. 
Impert, Laura, and Margaret Rubin. "The Mother at the Glen: The Relationship Between Mourning and Nostalgia." Psychoanalytic Dialogues 21.6 (2011): 691-706. Tandfonline.com. Taylor and Francis Online 1 Dec. 2011. Web. 5 Mar. 2019.

Joyce, James. Ulysses. Ed. Hans Walter Gabler. London: Bodley Head, 1986. Print.

Minhinnick, Robert. Interview by Eamon Bourke. Walesartsreview.org. Wales Arts Review Jul. 2017. Web. 15 Apr. 2019.

---. "Mouth to Mouth: A Recitation Between Two Rivers." Diary of the Last Man. Manchester: Carcanet, 2017. 25-52. Print.

---. "Nocturne." Diary of the Last Man. Manchester: Carcanet, 2017. 9. Print.

---. "Nostalgia." Diary of the Last Man. Manchester: Carcanet, 2017. 13. Print.

---. “Oyster Shells.” Diary of the Last Man. Manchester: Carcanet, 2017. 8. Print.

---. "Prophecy." Diary of the Last Man. Manchester: Carcanet, 2017. 7. Print.

---. "Questions of the Woman who Fell.” After the Hurricane. Manchester: Carcanet, 2002. 26-29. Print.

---. "Salvage." Selected Poems. Manchester: Carcanet, 1999. 12-13. Print.

---. "The Cormorant." King Driftwood. Manchester: Carcanet, 2008. 7-8. Print.

---. "The London Eye." Diary of the Last Man. Manchester: Carcanet, 2017. 12. Print.

---. "The Sand Orchestra." Diary of the Last Man. Manchester: Carcanet, 2017. Print.

Rees, Martin. Our Final Hour: A Scientist's Warning: How Terror, Error, and Environmental Disaster Threaten Humankind's Future In This Century -On Earth and Beyond. New York: Basic, 2003. Print.

Simmel, Georg. “The Ruin.” Ruins. Ed. Brian Dillon. London: Whitechapel Gallery, 2011. 10-19. Print.

Volkan, Vamik D. "Individuals and Societies as 'Perennial Mourners': Their Linking Objects and Public Memorials." On Death and Endings: Psychoanalysts' Reflections on Finality, Transformations and New Beginnings. Ed. Brent Willock, Lori C. Bohm and Rebecca C. Curtis. London: Routledge, 2007. 42-60. Print.

Wilson, A. N. "Home of Victorian Ghosts." The-tls.co.uk. The Time Literary Supplement 23 Jan. 2019. Web. 23 Apr. 2019.

Žižek, Slavoj. Living in the End Times. London: Verso, 2010. Print. 
Agata Handley is Assistant Professor in the Faculty of Philology at the University of Eódź. She is the author of Constructing Identity: Continuity, Otherness and Revolt in the Poetry of Tony Harrison (Peter Lang, 2016) and is currently continuing her research on contemporary British literature. The main areas of her academic interest are contemporary British and Canadian poetry with particular focus on the culture of the English North.

agatagrazyna@gmail.com 